This Journal is available in Telkom University online Journals

Jurnal Manajemen Indonesia

Journal homepage: journals.telkomuniversity.ac.id/ijm

\title{
Understanding Attitude towards Change
}

Ami Fitri Utami and Moch. Sandy Triady

Management Program, BINA NUSANTARA UNIVERSITY, Jakarta, Indonesia

\begin{abstract}
Business dynamics aimed to urge the organization to adapt in order to parlay their competitive advantage. By this, change attempts often inevitable as an effort to keep functioning on the dynamic condition. However, change in an organization is not easy, mainly when it deals with a human within the structure. This research aims to untangle the individual factor, which forms their attitude toward change. By this, the study determines two-variable such self-efficacy and employee's trust in a leader as a predictor of the employee attitudes toward change. Through the sample of 50 employees from a company which facing a change in business process, it was found that employees' self-efficacy and trust in leader positively related with the positive attitude toward change. Otherwise, the self-efficacy and trust in leader negatively influence the negative attitude toward change. Through the result, managers might gain insight that gaining trust in the executives and gaining employees' trust within their ability is imperative to acquire a positive attitude towards change.
\end{abstract}

Keywords-Attitude towards Change, Change, Self-Efficacy, Trust

\begin{abstract}
Abstrak
Dinamika bisnis akan terus mendorong organisasi untuk melakukan perubahan demi mencapai keunggulan daya saing yang mumpuni. Namun, perubahan bukanlah hal yang mudah diterima oleh anggota organisasi, terutama saat hal tersebut berimplikasi langsung terhadap mereka sebagai individu. Penelitian ini bertujuan untuk memahami bagaimana pengaruh antara keyakinan diri atau self-efficacy dan rasa percaya terhadap pemimpin atau trust in leader terhadap respon akan perubahan yang terjadi. Dengan menggunakan sampel sebanyak 50 karyawan dari satu organisasi yang sedang melakukan restrukturisasi ditemjkan bahwa baik rasa keyakinan akan kemampuan diri serta rasa percaya terhadap pemimpin dapat mempengaruhi respon karyawan terhadap perubahan yang ada.
\end{abstract}

Kata kunci-Attitude towards Change, Change, Self-Efficacy, Trust

\section{INTRODUCTION}

Current business condition is highly dynamic; with various turbulences occurred strikes firms. In this vein, changes are inevitable to be faced by organizations and the people inside. The fluctuating business challenges then acquired companies to develop themselves to be more innovative in doing business. This development is frequently acquiring changes both in minor or and significant scale in the organization. Organizational changes are currently a proliferating phenomenon due to the company's attempt to adapt to the current business condition. However, unlike its positive trends and proliferation, changes for organizations are not easy and often required psychological processes to be faced by a member of the organization. By this, a failure to consider such processes may strengthen the possibility of the change initiative failing (Schelz \& Zentes, 2006).

In discussing more about change, Linstone \& Mitroff (1994) aimed that change processes should also consider these three different perspectives or factors include technology, organizational, and people or personal perspectives. By this, Linstone \& Mitroff (1994) also claimed that from all of those three factors, the most important yet most challenging factor to be changed is the people or personal perspectives of the individual inside the organization. The individual perspective on the role of the organization is an important element of the 
success of change during the change process. In this case, the member's perspective on change usually projects how the employee's attitude towards various changes happened inside the firm. Rafferty, Jimmiesonn \& Armenakis in 2013 postulated that attitude toward organizational change pictured as an employee overall positive or negative evaluative response of a change initiative implemented by his or her organization. Thus, managing the human part of the organization frequently becomes a challenge due to the involvement of values, preferences, and attitudes toward the activity (Carnall, 1990).

Understand the employees' response towards change, might prepare leaders the solutions to overcome their response. As Beer \& Nohria (2000) postulated that most failures in organization change happened due to lack of strategy and trust, commitment, communication, and availability of resistance to change; understanding employee's attitudes towards change may avoid those causes. Understanding employee attitude towards change requires an individual-level analysis in an organization. In this case, individuals of the organization may react differently to the change process due to their differed perception of the event includes how they perceived their ability to face the change (Jimmieson, Terry \& Callan, 2004). On the other hand, Van Dam, Oreg \& Schyns (2008) also claimed that social interactions in an organization are imperative to form the success of the change, where trust also acts as part of the relationship between leaders and followers which reflect the intensities of the relationship

This study aimed to understand the individual perspective factor influencing their attitude towards change. In this vein, we consider self-efficacy and trust in the leader as part of the antecedents of the independent variable. Changes in the organization are currently inevitable. This phenomenon occurs due to nowadays business dynamics, which push organizations to develop their structure, process, and also people. Unfortunately, not all of the organization members are responding to the change positively. In other words, there are variations between employee response upon the change event in the organization, and these variations occurred by various predictors in the organization. There are a number of things that can be done including discussing more about change and organizational members, understanding employee attitudes towards change may be important for managers. By this, understanding the employee response upon the change will help the manager to shape and develop a swifter change strategy customized into current employment conditions and perspectives. On the other hand, while most change management studies focus on the macro-level of organization, this study also will strengthen the change management field studies from a micro-level perspective by considering the individual perspective over their abilities and their leader.

\section{THEORETICAL FRAMEWORK}

Employee attitude towards organizational change can be defined as their evaluative judgment, both positive and detrimental to the change event in the organization (Lines, Selart, Espedal \& Johansen, 2005). Likewise, Neiva. Ros and Torres (2005) aimed that attitude towards change can be described as one's beliefs, behavior, and feelings during the change process in the organization. Thus, change can be welcomed with excitement or even anger and fear, which usually projected in employee positive or harmful behavior. (Vakola, Tsaousis \& Nikolaou, 2003). Neiva et al., (2005) postulated that employee behavior to respond to organizational change could be divided into three different structures. In this vein, those structures include acceptance of change, fears about change, and cynicism to change. By this, if the members embrace the organization change positively, the probability for them to adapt easier will be higher than those who resist the change. Moreover, Dawson (1994) also noted that resistance to organizational change might result from one or a combination of factors such as a substantive change in job, reduction in economic security, psychological threats, disruption of social arrangements, and lowering of status. Hence, the employee attitude towards change in an organization can be varied from one to another. By this, some employees possess cynicism towards change, fears towards change, and also the acceptance towards change (Neiva et al., 2005). These responses may differ from one employee to another.

As previously discussed, understanding employees' attitudes towards change involve individual factor analysis. Dawson, in 1994, postulates that employee's response towards change may result from the combination of various factors, including psychological factors. By this, Dawson in 1994 postulated that the resistance of change might occur when the change psychologically threatens the employee. In this matter, one should be threatened when one feels high of insecurity about the event in the organization. Self-efficacy related to change in an organization can be defined as an employee's perception of their ability to get their jobs done well within the changing work environment (Jimmieson et al., 2004). In this vein, the employee's different self- 
efficacy resulted in a different response to change events in the organization. The tendency will be different as the higher the employee confidence about them; the more positive they will embrace the change process. Otherwise, employees who doubt their abilities tend to focus on their insecurity rather than the organization's change goals (Jimmieson et al., 2014). By this, along with Jimmieson et al., (2014), we argue that self-efficacy will be one of the employees' predictors of their response towards change in the organization. Despite the internal self-factor of the employee, Van Dam et al., (2008) aimed that the daily social interaction might imperative for change success includes how the interactions between peers and also leaders-followers, which its intensities may depict on the employee's trust to their leaders. As Dirks \& Ferrin (2002) postulated that trust in a leader might influence the employee's job attitudes includes belief and response in the information. Thus, since the change in an organization involves leaders and the spread of information on the change event, it can be presumed that employees' trust with their leader may influence their attitude towards the change in the organization. Moreover, there are two hypotheses within this research, the 1st hypothesis is self-efficacy will influence to the positive and negative attitude towards change, and the 2nd hypothesis is trust in leader will influence employee's positive and negative attitude towards change.

\section{METHODOLOGY}

This research uses the quantitative method in order to examine the hypotheses and reach its' objectives. By this, the data gathering process is by using a self-administered questionnaire, which consisted of up to 33 questions. The research also conducted in a family-owned manufacturing company in West Java, which consisted of 78 employees. This research uses a survey method, which included all population as the sample to gain the primary data. By this, 78 questionnaires are being spread to all of the employees. However, there are only 50 questionnaires able to be used among all 70 responses due to the uncompleted data. Data analysis was done using PLS-SEM due to the limited number of data.

There are two independent variables and one dependent variable in this research. The independent variable resembled by individual's trust in leader and self-efficacy while the dependent variables portray as the individual attitude towards change event. The measurement is used in this research developed by prior researches. The attitude toward change, which define as individual response to the change event in organization are divided into two main dimensions such positive and negative attitudes. In this condition, both positive and negative attitudes toward the change event are measured from the attitude toward change scale by Neiva et al., (2015). The negative attitude toward change included up to 13 questions such change that already planned oftentimes not being run; we often cooperate to avoid change, change often happen without clear reasons, unclear information from the change resulted into biased expectations, change is frightening due to its' potential loss of power. Moreover, the positive attitude toward change comprised of up to 5 questions includes change is an important thing to add a new breeze to the organization, change which happens here often help its' employees better, my friends and I always support the change agenda within the company.

The next variable is the self-efficacy adopted by the scale of Chen, Gully \& Eden (2001). In this case, the self-efficacy defined as one's belief of their own capabilities to meet situational demands (Chen et al., 2001). In this research, self-efficacy measured in uni-dimension by eight items of question developed by Chen et al., (2001) named the New General Self-efficacy Scale which includes I will be able to achieve most of the goals of myself, I am able to accomplish even in facing difficult task and etc. .Moreover, the last variable is trust in the leader, which measured by the adaptation from Podsakoff, MacKenzie, Moorman \& Fetter (1990) which developed the trust in leader scale from Cook and Wall (1980). The trust in leader define as the individual's faith and loyalty to the leader (Podsakoff et al., 1990). There are mainly six questions within this variable; the sample question includes I have loyalty to my leader, I believe that my leader possess a reliable personality, I believe that my leader always being fair to his or her subordinates. The six questions divided into three main dimensions include the interpersonal trust, faits and intentions, and sense of loyalty.

\section{RESULT}

In analysing the data, two steps methods are being used to unveil the fitness of both inner and outer model. From the below table (Table.1), it can be seen that this research gathered 50 employees as the sample. By this, not all the employees' within the company are able to participate in the research. On the other hand, most of the employees who gathered the questionnaire is also male employees. This might be caused by the nature of the 
company's demography where most of them are male due to the form of its business as a small manufacturing company. Moreover, Table. 2 shows the validity and reliability of the construct through the outer model. In this matter, through the Cronbach Alpha score, which higher than 0,8 and composite reliability score higher than 0.7, the reliability can be accepted. Moreover, the validity can be seen through the AVE (average variance extracted score) where all of the constructed variables are scored higher than 0.5.

Table 1. Sample Demography

\begin{tabular}{lll}
\hline Description & Male & Female \\
\hline Gender & 32 & 18 \\
\hline
\end{tabular}

Table 2. Validity \& Reliability Result

\begin{tabular}{llll}
\hline Variables & $\begin{array}{l}\text { Cronbach } \\
\text { Alpha }\end{array}$ & $\begin{array}{l}\text { Composite } \\
\text { Reliability }\end{array}$ & AVE \\
\hline Self-efficacy & 0.973121 & 0.977037 & 0.841754 \\
Trust in leader & 0.972289 & 0.985024 & 0.835060 \\
Positive attitude toward change & 0.940308 & 0.954559 & 0.807869 \\
Negative attitude toward change & 0.983477 & 0.977519 & 0.878823 \\
\hline
\end{tabular}

This study aimed to test two hypotheses, which reflected the relationship between self-efficacy, trust in the leader, and the employee's attitude towards change both positive and negative attitude. The first hypothesis is pointed out that self-efficacy will significantly influence employee's attitudes towards change both positive attitudes and negative attitudes. On the other hand, the second hypothesis is projected that trust in leaders will significantly influence the employee's attitude towards change, both a positive attitude and a negative attitude. From the data processing using Smart PLS 2, it was found that both of the hypotheses are supported. The first hypotheses are supported due to the significance of T-statistic value among the relationship between self-efficacy to positive and negative toward change, which sequentially reached 7.59 and 8.51 (significant $\mathrm{t}>1.96$ ). Likewise, the second hypothesis also supported the significance of $\mathrm{T}$ value, where trust in the leader and negative attitude toward change scored 5.12 and trust in leader to the positive attitude toward change scored at 2.76 (significant, $\mathrm{t}>1.96$ ).

Despite the significance, the nature of correlation also differed among each hypothesis. In this matter, the path coefficient of each variables relationship also shows a different form of relationship. In this matter, the relationship between self-efficacy and negative attitude toward change portrayed to be negative, with the path coefficient scored at -0.405 . Otherwise, the self-efficacy and positive attitude toward change reflected to be positive, with the path coefficient scored at 0.969. By this, the higher the employee's self-efficacy, the lower their negative attitude toward change. Likewise, when an employee possesses a higher self-efficacy, they tend to have a higher positive attitude toward change. Moreover, this also happened to the relationship between trust in the leader and the positive and negative attitude toward change. By this, the relationship between trusts in leader to employees' negative attitude toward change appeared to be negative with path coefficient scored at -0.177 ; otherwise, the relationship between trusts in leader to the positive attitude toward change is in a positive form with path coefficient scored at 0.264 . Hence, it can be seen that the higher the employees' trust in the leader, the lower their negative attitude toward change. Likewise, the higher the employee's trust in leader will also lead to a higher positive response of employees toward the change event. By this, it can be concluded that both of the research hypotheses are supported. Furthermore, the notion of self-efficacy and trust in leaders will positively influence a positive attitude toward change and negatively influence the negative attitude toward change. Looking deeper at the R2 score, the negative attitude toward change scored at 0.87 , while the positive attitude toward change also scored at 0.84 . These scores show that negative and positive attitudes toward change might be $84 \%$ and $87 \%$ explained by the condition of employee's self-efficacy and trust in the leader. This result shows a quite huge role of the two independent variables in explaining the changes and differences of the dependent variable. 


\section{CONCLUSSION \& RECOMMENDATION}

This study aimed to examine the role of self-efficacy and trust in leaders to employees' attitudes toward change. By this, there are different responses by employees in responding to the change event within the company. Previous scholars already stated that it is due to the individual matter, such as their trust to the selfability and their trust to the company's leader. Through the case of one family-owned manufacturer company in West Java, which currently applies a significant change in its' business process, this research gain 50 employees' data regarding their attitude in responding to change. From the result analysis, it can be confirmed that self-efficacy positively influences the positive attitude toward change. The positive attitude toward change is part of an employee's attitude toward change by Neiva et al., (2005), which reflected through the acceptance of employees to the change event. The research result means that when an employee possesses a higher selfefficacy, they tend to react positively toward change by accepting it. This might be happened due to their sense of confidence in their ability to do their job. Hence insecurity is less. Moreover, the positive relationship also happened among the trust in the leader and a positive attitude toward change. This means that higher trust in leaders might result in a higher acceptance by an employee toward the change. This might be caused by the emotional security of employees when they believe that their leader will do the best for them. Hence, their response to the change also better.

The above discussion also reflected the other result of the research. There is a negative relationship between the trust in leader, self-efficacy, and the negative attitude toward change. The result shows that the negative attitude toward change shows the cynicism and fear of employees to the change event. The availability of high self-efficacy and high trust in leaders will also decrease this response to change. Again, self-efficacy and trust will create a sense of security of work within the organization. While the role of self-efficacy and trust in a leader highly resemblance to the employee's attitude toward change, the organization might also consider these factors when they are planning to change organizations, either minor or significant change. In this case, previous research such George \& Camarata (1996) concluded that individual's resistance to change might triggered by the availability of negative symbolism includes the perception of inability to follow the change. In this research, self-efficacy portrays one's faith on their capabilities towards particular situations. A good sense of this efficacy might reduce the negative symbolism which referred by Bird (1991) and George \& Camarata (1996). Moreover, this research also supports the arguments of Radzi \& Othman (2014) which define that trust in management might reduce the employee's resistance to change. In this case, employee will be more convinced to involve more with the change, when they trust that their leaders are capable to lead the transformation. Hence, providing a higher trust to the board member as their leader, as well as the trust of the employee's direct supervisor, might help employees to accept the change event. On the other hand, companies also need to consider how strong the employee feels their fluency in their job. This also might help the organization to understand their starting point to see the employees' attitude toward change

\section{REFERENCES}

Beer, M., \& Nohria, N. (2000). Cracking the code of change. HBR's 10 must reads on change, 78(3), 133-141. Carnall, C.A. (1990). Managing Change in Organization. Michigan: Prentice Hall.

Chen, G., Gully, S. M., \& Eden, D. (2001). Validation of a new general self-efficacy scale. Organizational research methods, 4(1), 62-83.

Cook, J., \& Wall, T. (1980). New work attitude measures of trust, organizational commitment and personal need non-fulfillment. Journal of Occupational Psychology, 53, 39-52.

Dirks, K.T., \& Ferrin, D.L. (2002). Trust in leadership: Meta-analytic findings and implications for research and practice. Journal of Applied Psychology, 87, 611-628.

Dawson, P. M. (1994). Organizational change: A processual approach. Paul Chapman Publishing.

Ertürk, A. (2008). A trust-based approach to promote employees' openness to organizational change in Turkey. International Journal of Manpower, 29(5), 462-483.

George, G., \& Camarata, M. (1996). Managing Instructor Cyberanxiety: The Role of Self-Efficacy in Decreasing Resistance to Change. Educational Technology, 36(4), 49-54.

Jimmieson, N. L., Terry, D. J., \& Callan, V. J. (2004). A longitudinal study of employee adaptation to organizational change: the role of change-related information and change-related self-efficacy. Journal of occupational health psychology, 9(1), 11.

Lines, R., Selart, M., Espedal, B., \& Johansen, S. T. (2005). The production of trust during organizational change. Journal of Change Management, 5(2), 221-245. 
Linstone, H.A. \& Mitroff, I.I. (1994). Challenge of the 21st Century, the Managing Technology and Ourselves in a Shrinking World. New York: SUNY Press.

Neiva, E.R., Ros, M. \& Torres, G.M. (2005). Attitudes towards Organizational Change: Validation of a Scale. Psychology in Spain, 9, 81-90

Podsakoff, P. M., MacKenzie, S. B., Moorman, R. H., \& Fetter, R. (1990). Transformational leader behaviors and their effects on followers' trust in leader, satisfaction, and organizational citizenship behaviors. The leadership quarterly, 1(2), 107-142.

Radzi, N. I. M., \& Othman, R. (2014). Resistance to change: The moderating effects of leader-member exchange and role breadth self-efficacy. Journal of Advanced Management Science Vol, 4(1), 72-76.

Rafferty, A.E., Jimmiesonn N.L. \& Armenakis, A.A. (2013) Change Readiness: A Multilevel Review. Journal of Management, 39(1), 110-135

Schelz, C. \& Zentes, J. (2006). Strategic Management - New Rules for Old Europe. Germany: Die Deutsche Bibliothek.

Van Dam, K., Oreg, S., \& Schyns, B. (2008). Daily work contexts and resistance to organisational change: The role of leader-member exchange, development climate, and change process characteristics. Applied psychology, 57(2), 313-334.

Vakola, M., Tsaousis, I., \& Nikolaou, I. (2004). The role of emotional intelligence and personality variables on attitudes toward organisational change. Journal of managerial psychology, 19(2), 88-110. 